\title{
The Role of Sediment Resuspension in the Remobilization of Particulate-Phase Metals from Coastal Sediments
}

Supporting Information

Linda H. Kalnejais ${ }^{1 *}$, William R. Martin ${ }^{1}$, Richard P. Signell ${ }^{2}$, Michael H. Bothner ${ }^{2}$

${ }^{1}$ Woods Hole Oceanographic Institution, Woods Hole, MA 02543

${ }^{2}$ US Geological Survey, Woods Hole, MA 02543

${ }^{*}$ Corresponding author present address: University of California, Berkeley

Earth and Planetary Sciences, McCone Hall, Berkeley CA 94720. email:linda_k@alum.mit.edu

11 pages, 4 Figures, 5 Tables

December 19, 2006 


\section{Erosion Chamber and Shear Stress Calibration}

The erosion chamber is shown in Figure S-1. The imposed bottom shear stress is a function of the propeller rotation rate. Sieved sand was used to calibrate the chamber. The rotational rate of the propeller was incrementally increased until significant movement of sand grains was observed. The shear stress required to resuspend the known grain size was determined from a Shield's threshold curve. The Shields's parameter was assumed to have a $20 \%$ uncertainty [3]. The analytical formula fitted to the Shield's curve by Soulsby and Whitehouse and extended to finer grain sizes [4] was used to calculate the critical shear stress. The results of the calibration (Figure S-2) show a linear response between the rotation rate and shear stress at the sediment-water interface.

\section{Sampling and Trace Metal Analysis}

The trace metal content of the sediment samples was determined at the United States Geological Survey in Denver following the method of Briggs and Meier [5]. Certified reference materials from the National Research Council of Canada, marine sediment BCSS-1 and MESS-1, lake sediments LKSD-3 and harbor sediment PACS-2, the National Institute for Science and Technology standard reference material NIST-2709 and U.S.G.S marine sediment reference material MAG-1 were all run with each batch of samples (up to 50 samples). The data for $\mathrm{Fe}, \mathrm{Mn}, \mathrm{Cu}, \mathrm{Ag}$ and $\mathrm{Pb}$ were all within the published values for these elements. Replicate samples for $\mathrm{Fe}, \mathrm{Mn}, \mathrm{Cu}$ and $\mathrm{Pb}$ varied by less than $5 \%$ and varied by less than $10 \%$ for $\mathrm{Ag}$.

The metal content of the particulate material on the filter membranes was determined with the total sediment digest method of Briggs and Meier [5] but the digestion and analysis were performed at the Woods Hole Oceanographic Institution. Unused filter membranes and empty vials were also taken through the procedure to determine the trace metal concentrations associated with the membranes and digestion procedures. A Finnigan Element 2 ICP-MS was used to quantify the digest concentrations, with $50 \mu \mathrm{L}$ of digest diluted with 


\section{Erosion Chamber}

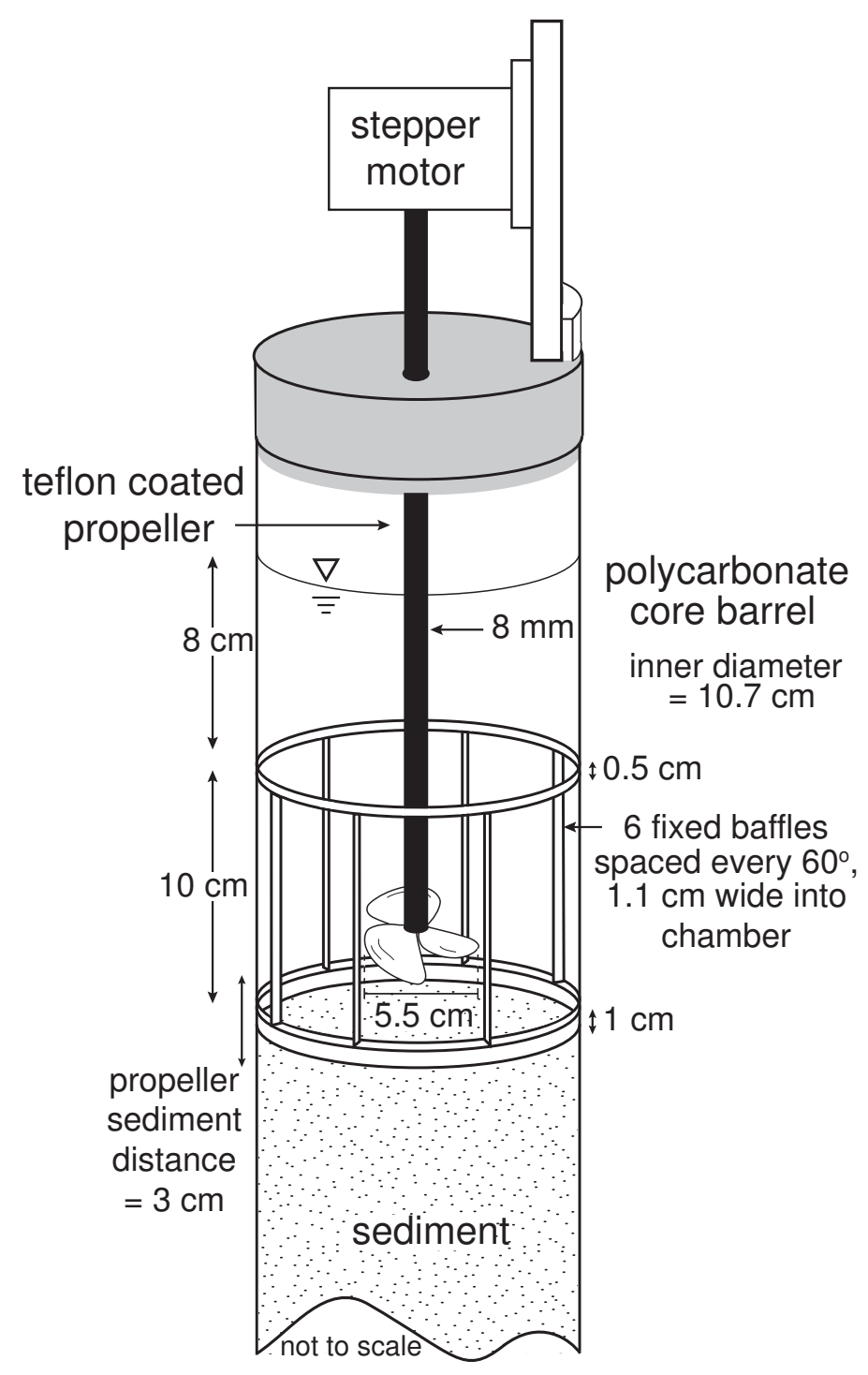

Figure S-1: The modified EROMES erosion chamber showing the experimental geometry $[1,2]$. The design for EROMES was provided by Dr Rolf Reithmüller of GKSS, Germany. Drawing by M. Sulanowska. 

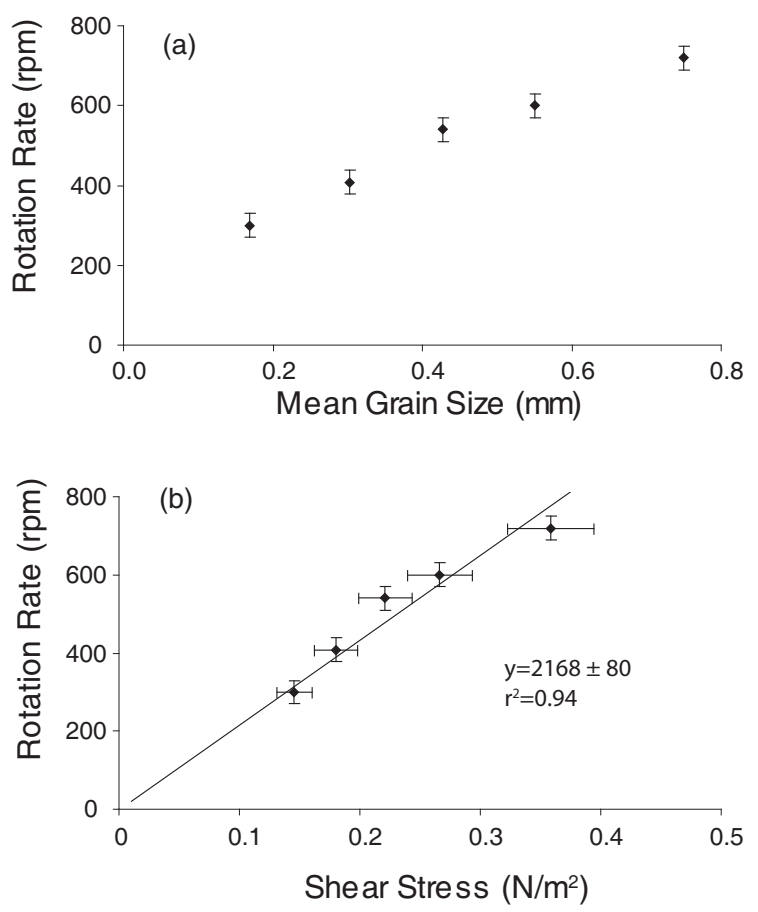

Figure S-2: Erosion chamber calibration curves. (a) Rotation rate at which grains were first held in motion. (b) Shear stress calibration calculated from the Shield's curve for each grain size.

a $5 \%$ nitric acid solution containing 0.5 ppb In internal standard solution. A $5 \%$ nitric acid matrix external calibration as well as standard additions of a multi-element standard (Alfa Aesar) to selected samples were used to quantify the sample concentrations.

Acid volatile sulfide was determined by a method adapted from Allen [6]. Massachusetts Bay sediment were stored at $-40^{\circ} \mathrm{C}$ for two years prior to AVS analysis. Hingham Bay sediments were stored at $-40^{\circ} \mathrm{C}$ under a nitrogen atmosphere in mylar gas tight bags for 1 year prior to AVS analysis. The $\mathrm{H}_{2} \mathrm{~S}$ generated by the method of Allen was trapped in $50 \mathrm{mls}$ of $2.6 \%$ zinc acetate in $1.5 \mathrm{M} \mathrm{NaOH}$ and the sulfide concentration determined by the method of Cline [7]. Allen [6] found that frozen sediments stored for 5 months gave values between $80-90 \%$ of the initial AVS value. These samples have been stored for longer durations but at colder temperatures so it is likely that the AVS values reported do underestimate the initial AVS concentrations. Deeper samples from the MB core have AVS concentrations up to $3 \mathrm{mmol} / \mathrm{kg}$. Samples preserved for the same length of time do have 
Table S-1: Sampling Dates and Core Inventory for Hingham Bay

\begin{tabular}{|c|c|c|c|c|}
\hline Date & $\begin{array}{l}\text { Core } \\
\text { Number }\end{array}$ & $\begin{array}{l}\text { Surface Sampling } \\
\text { Resolution }\end{array}$ & $\begin{array}{l}\text { Sampling } \\
\text { Atmosphere }\end{array}$ & Analyte \\
\hline Jan-02 & $\begin{array}{l}\text { Core } 1 \\
\text { Core } 2 \\
\text { Core } 3\end{array}$ & $\begin{array}{l}3 \mathrm{~mm} \\
3 \mathrm{~mm} \\
2 \mathrm{~mm}\end{array}$ & $\begin{array}{l}\text { nitrogen } \\
\text { nitrogen } \\
\text { air }\end{array}$ & $\begin{array}{l}\text { Porewaters, solid phase } \\
\text { Porewaters } \\
\text { Porosity }\end{array}$ \\
\hline Jul-02 & $\begin{array}{l}\text { Core } 1 \\
\text { Core } 2 \\
\text { Core } 3\end{array}$ & $\begin{array}{l}3 \mathrm{~mm} \\
3 \mathrm{~mm} \\
2 \mathrm{~mm}\end{array}$ & $\begin{array}{l}\text { nitrogen } \\
\text { nitrogen } \\
\text { air }\end{array}$ & $\begin{array}{l}\text { Porewaters } \\
\text { Porewaters, solid phase } \\
\text { Porosity }\end{array}$ \\
\hline Sep-02 & $\begin{array}{l}\text { Core } 1 \\
\text { Core } 2 \\
\text { Core } 3\end{array}$ & $\begin{array}{l}3 \mathrm{~mm} \\
3 \mathrm{~mm} \\
2 \mathrm{~mm}\end{array}$ & $\begin{array}{l}\text { nitrogen } \\
\text { nitrogen } \\
\text { air }\end{array}$ & $\begin{array}{l}\text { Porewaters, solid phase } \\
\text { Porewaters } \\
\text { Porosity }\end{array}$ \\
\hline Oct-03 & $\begin{array}{l}\text { Core } 1 \\
\text { Core } 2 \\
\text { Core } 3 \\
\text { Core } 4\end{array}$ & $\begin{array}{l}3 \mathrm{~mm} \\
2 \mathrm{~mm} \\
5 \mathrm{~mm}\end{array}$ & $\begin{array}{l}\text { nitrogen } \\
\text { air } \\
\text { air }\end{array}$ & $\begin{array}{l}\text { Porewaters } \\
\text { Porosity } \\
\text { Solid phase, porosity } \\
\text { Erosion Experiment }\end{array}$ \\
\hline Jun-04 & $\begin{array}{l}\text { Core } 1 \\
\text { Core } 2 \\
\text { Core } 3 \\
\text { Core } 4 \\
\text { Core } 5\end{array}$ & $\begin{array}{l}3 \mathrm{~mm} \\
3 \mathrm{~mm} \\
5 \mathrm{~mm} \\
2 \mathrm{~mm}\end{array}$ & $\begin{array}{l}\text { nitrogen } \\
\text { nitrogen } \\
\text { air } \\
\text { air }\end{array}$ & $\begin{array}{l}\text { Porewaters, AVS } \\
\text { Porewaters, solid phase } \\
\text { solid phase, porosity } \\
\text { Porosity } \\
\text { Erosion Experiment }\end{array}$ \\
\hline
\end{tabular}

measurable AVS, indicating that the low levels of AVS in the surface samples of the MB site is due to the geochemical profile in the sediments, rather than a preservation artifact.

Porosity was determined gravimetrically by drying the sediments to a constant weight in a $60^{\circ} \mathrm{C}$ oven and assuming a grain density of $2.65 \mathrm{~g} \mathrm{ml}^{-1}$ [8].

Acidified porewater samples were analyzed for iron with a Hitachi graphite furnace atomic absorption spectrophotometer (GFAAS), quantified with a matrix matched 5 point external calibration. The detection limit was $2 \mu \mathrm{mol} / \mathrm{L}$. Porewater sulfide was determined by the method of Cline [7]. The detection limit was $1 \mu \mathrm{mol} / \mathrm{L}$. 
Table S-2: Sampling Dates and Core Inventory for Massachusetts Bay

\begin{tabular}{|c|c|c|c|c|}
\hline Date & $\begin{array}{l}\text { Core } \\
\text { Number }\end{array}$ & $\begin{array}{c}\text { Surface Sampling } \\
\text { Resolution }\end{array}$ & $\begin{array}{l}\text { Sampling } \\
\text { Atmosphere }\end{array}$ & Analyte \\
\hline Feb-02 & $\begin{array}{l}\text { Core } 1 \\
\text { Core } 2 \\
\text { Core } 3 \\
\text { Core } 4\end{array}$ & $\begin{array}{l}3 \mathrm{~mm} \\
3 \mathrm{~mm} \\
3 \mathrm{~mm} \\
2 \mathrm{~mm}\end{array}$ & $\begin{array}{l}\text { nitrogen } \\
\text { nitrogen } \\
\text { nitrogen } \\
\text { air }\end{array}$ & $\begin{array}{l}\text { Porewaters } \\
\text { Porewaters } \\
\text { Porewaters, solid phase } \\
\text { Porosity }\end{array}$ \\
\hline May-02 & $\begin{array}{l}\text { Core } 1 \\
\text { Core } 2 \\
\text { Core } 3 \\
\text { Core } 4\end{array}$ & $\begin{array}{l}3 \mathrm{~mm} \\
3 \mathrm{~mm} \\
3 \mathrm{~mm} \\
2 \mathrm{~mm}\end{array}$ & $\begin{array}{l}\text { nitrogen } \\
\text { nitrogen } \\
\text { nitrogen } \\
\text { air }\end{array}$ & $\begin{array}{l}\text { Porewaters } \\
\text { Porewaters } \\
\text { Porewaters, solid phase } \\
\text { Porosity }\end{array}$ \\
\hline Oct-02 & $\begin{array}{l}\text { Core } 1 \\
\text { Core } 2 \\
\text { Core } 3\end{array}$ & $\begin{array}{l}3 \mathrm{~mm} \\
3 \mathrm{~mm} \\
2 \mathrm{~mm}\end{array}$ & $\begin{array}{l}\text { nitrogen } \\
\text { nitrogen } \\
\text { air }\end{array}$ & $\begin{array}{l}\text { Porewaters } \\
\text { Porewaters, solid phase } \\
\text { Porosity }\end{array}$ \\
\hline Mar-03 & Core 1 & $5 \mathrm{~mm}$ & air & solid phase \\
\hline Jun-03 & Core 1 & $5 \mathrm{~mm}$ & air & solid phase \\
\hline Sept-03 & $\begin{array}{l}\text { Core } 1 \\
\text { Core } 2 \\
\text { Core } 3 \\
\text { Core } 4\end{array}$ & $\begin{array}{l}3 \mathrm{~mm} \\
3 \mathrm{~mm} \\
5 \mathrm{~mm}\end{array}$ & $\begin{array}{l}\text { nitrogen } \\
\text { nitrogen } \\
\text { air }\end{array}$ & $\begin{array}{l}\text { Porewater nutrients, AVS } \\
\text { Porewaters, solid phase } \\
\text { Solid phase } \\
\text { Erosion Experiment }\end{array}$ \\
\hline
\end{tabular}




\section{Hydrodynamic Modeling of Shear Stresses}

To determine the temporal variation of bottom shear stresses at the Hingham Bay site a modeling and statistical approach was used. Hourly wind data collected by the National Data Buoy Center (NOAA), buoy number 44013 was available for a 19.4-year time period, August 1984 to December 2003. This buoy is located in Massachusetts Bay, $20.6 \mathrm{~km}$ northeast of the Hingham Bay site. Wind stresses were calculated from the formulation of Large and Pond [9]. Tidal currents for the 19.4 year period were predicted using tidal constituents for the Hingham Bay site. The constituents were determined by running a 100-m horizontal resolution depth-averaged tidal model TRIM [10] driven by the 5 dominant NOAA tidal constituents for Boston Harbor (O1, K1, N2, M2, S2). The tidal constituents for the HB site were determined using the program of Pawlowicz et al. [11] and a 19.4-year period prediction created from the tidal constituents.

The wind-driven currents for the 19.4-year period were predicted using a transfer function between wind and current determined from the hydrodynamic model for each 10 degrees of wind angle. A constant transfer factor for each wind angle was determined, and the input series of wind-stress angle and magnitude converted into current angle and magnitude. Wave driven currents for the 19.4-year period were determined by calculating

the wave height and period using the shallow water, fetch limited wave formula [12]. The bottom orbital velocities were calculated using the explicit method detailed in Dean and Dalyrymple [13].

For waves and currents exceeding $0.01 \mathrm{~m} \mathrm{~s}^{-1}$, the Grant and Madsen [14] wave-current interaction formula was used to calculate combined shear stress. The depth-averaged currents (tide + wind-driven) were converted to $1 \mathrm{~m}$ above bottom using the model drag coefficient $\left(c_{d}=0.003\right)$. A constant physical bottom roughness of $\mathrm{k}_{b}=0.0001 \mathrm{~m}$ was assumed.

\section{Sediment Results}


Table S-3: Chemical Characteristics of Surface Sediments Collected with the Erosion Experiments Cores

\begin{tabular}{lcccccccc}
\hline Sampling & Depth & \multicolumn{6}{c}{ Surface Solid Phase Content (mmol/kg dry weight) } \\
Date & $(\mathrm{mm})$ & $\mathrm{Fe}$ & $\mathrm{Mn}$ & $\mathrm{Ag}$ & $\mathrm{Pb}$ & $\mathrm{Cu}$ & AVS & \%OC \\
\hline Hingham Bay & & & & & & & & \\
Sept. 2003 & $0-5$ & 755 & 12.3 & 0.023 & 0.34 & 1.04 & n.a & 2.7 \\
June 2004 & $0-3$ & 812 & 11.9 & 0.027 & 0.37 & 1.03 & 1.8 & 3.3 \\
June 2004 & $3-6$ & 802 & 11.6 & 0.024 & 0.37 & 1.00 & $3.9^{*}$ & 3.4 \\
Massachusetts Bay & & & & & & & & \\
Oct. 2003 & $0-5$ & 479 & 9.1 & 0.006 & 0.3 & 0.49 & n.d & 1.8 \\
\hline *-9 mm sample & & & & & & & & \\
n.d. - not detected & & & & & & & &
\end{tabular}

Table S-4: Porosity Profiles for each Sampling Site

\begin{tabular}{lccccc}
\hline $\begin{array}{l}\text { Depth } \\
(\mathrm{mm})\end{array}$ & $\begin{array}{c}\text { MB } \\
\text { October-02 }\end{array}$ & $\begin{array}{c}\text { MB } \\
\text { February-2004 }\end{array}$ & $\begin{array}{c}\text { MB } \\
\text { May-04 }\end{array}$ & $\begin{array}{c}\text { HB } \\
\text { October-03 }\end{array}$ & $\begin{array}{c}\text { HB } \\
\text { June-04 }\end{array}$ \\
\hline $0-2$ & 0.86 & 0.88 & 0.80 & 0.88 & 0.92 \\
$2-4$ & 0.85 & 0.90 & 0.71 & 0.84 & 0.92 \\
$4-6$ & 0.85 & 0.88 & 0.68 & 0.82 & 0.9 \\
$6-8$ & 0.84 & 0.84 & 0.70 & 0.82 & 0.89 \\
$8-10$ & 0.83 & 0.88 & 0.69 & 0.84 & 0.89 \\
\hline
\end{tabular}

Table S-5: Characteristics of Overlying Water used in Erosion Experiments

\begin{tabular}{lccc}
\hline & $\begin{array}{c}\text { Salinity } \\
(\mathrm{ppt})\end{array}$ & $\begin{array}{c}\text { Oxygen } \\
(\mathrm{mg} / \mathrm{L})\end{array}$ & $\begin{array}{c}\text { Temp } \\
\left({ }^{\circ} \mathrm{C}\right)\end{array}$ \\
\hline HB Oct 03 & 31.5 & 235 & 13 \\
HB June 04 & 31 & 280 & 14 \\
MB Sept 03 & 32 & 234 & 13 \\
\hline
\end{tabular}



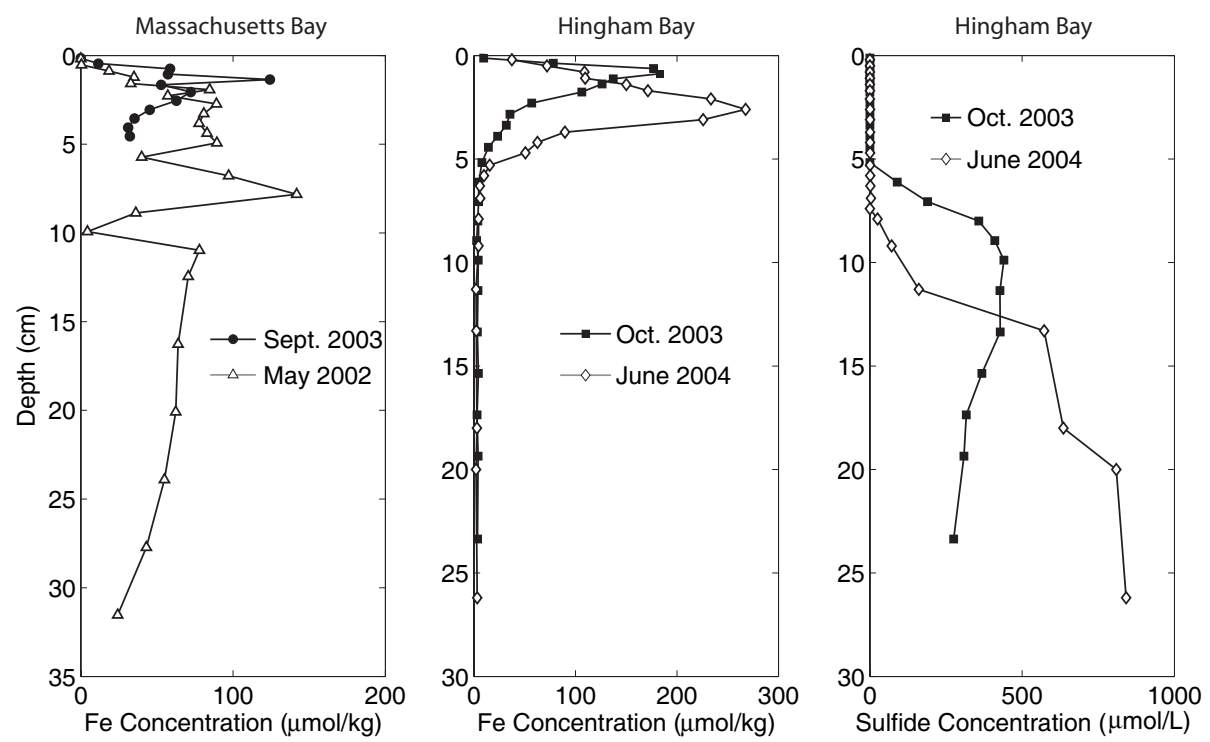

Figure S-3: Iron and Sulfide porewater profiles for Hingham Bay and Massachusetts Bay collected at the same time as each erosion experiment. An additional MB profile from May 2002 is also shown. Sulfide was not detected in the MB cores.
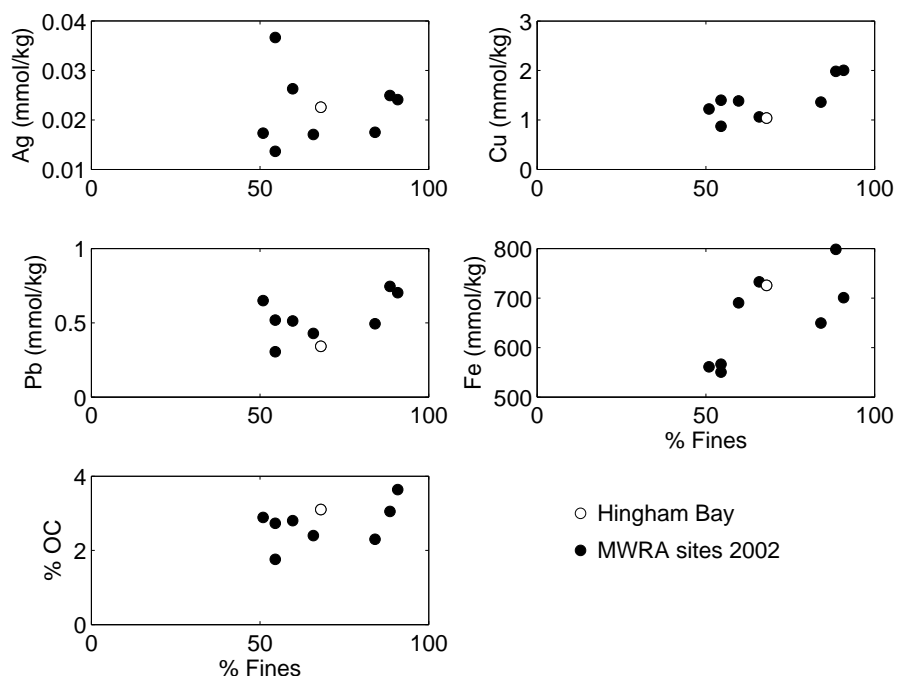

- Hingham Bay

- MWRA sites 2002

Figure S-4: Surface solid phase metal concentrations measured in 2002 by Lefkovitz et al. [15] for 8 other fine-grained sites within Boston Harbor. The Hingham Bay surface concentrations given in Table 1 are also shown. 


\section{References}

[1] Tolhurst, T.; Riethmuller, R.; Paterson, D. In situ versus laboratory analysis of sediment stability from intertidal mudflats. Cont. Shelf Res. 2000, 20, 1317-1334.

[2] Andersen, T.; Jensen, K.; Lund-Hansen, L.; Mouritsen, K.; Pejrup, M. Enhanced erodibility of fine-grained marine sediments by Hydrobia ulvae. J. Sea Res. 2002, 48, $51-58$.

[3] Ravens, T. Sediment Resuspension in Boston Harbor, Ph.D. Thesis, Massachusetts Institute of Technology, 1997.

[4] Soulsby, R.; Whitehouse, R. Threshold of sediment motion in coastal environments. In Pacific Coasts and Ports '97. Proceedings, Vol. 1; University of Canterbury, New Zealand, 1997.

[5] Briggs, P.; Meier, A. The determination of forty-two elements in geological materials by inductively coupled mass spectrometry, USGS Open File Report 1999-166, 1999.

[6] Allen, H.; Fu, G.; Deng, B. Analysis of acid-volatile sulfide (AVS) and simultaneously extracted metals (SEM) for the estimation of potential toxicity in aquatic sediments. Environ. Toxicol. Chem. 1993, 12, 1441-1453.

[7] Cline, J. Spectrophotometric determination of hydrogen sulfide in natural waters. Limnol. Oceanogr. 1969, 14, 454-458.

[8] Manheim, F.; Dwight, L.; Belastock, R. Porosity, density, grain density and related physical propoerties of sediments form the Red Sea drill cores. In Initial Report Deep Sea Drilling Program; Whitmarsh, R.; Waser, O.; Ross, D., Eds.; U.S. Govt. Printing Office: Washington, D.C., 1974.

[9] Large, W.; Pond, S. Open ocean momentum flux measurements in moderate to strong wind. J. Phys. Oceanogr 1981, 11, 324-336. 
[10] Signell, R.; Butman, B. Modeling tidal exchange and dispersion in Boston Harbor. J. Geophys. Res.-Oceans 1992, 97, 15591-15606.

[11] Pawlowicz, R.; Beardsley, B. B.; Lentz, S. Classical tidal harmonic analysis including error estimates in MATLAB using T_TIDE. Comput. Geosci. 2002, 28, 929-937.

[12] U.S. Army Corps of Engineers, Coastal Engineering Research Center, Vicksburg, MS "Shore Protection Manual", 1984.

[13] Dean, R.; Dalyrymple, R. Water wave mechanics for engineers and scientists; World Scientific: Teaneck, NJ, 1991.

[14] Grant, W.; Madsen, O. Combined wave and current interaction with a rough bottom. J. Geophys. Res. 1979, 84, 1797-1808.

[15] Lefkovitz, L.; Wisneski, C.; Hunt, C. Trends In Sediment Contaminant Concentrations In Northern Dorchester Bay And Other Boston Harbor Stations, 1990-2002, Technical Report 2005-01, Massachusetts Water Resources Authority, 2006. 